\title{
Mock turtles
}

\author{
One reptile enthusiast, working with a handful of academics, has described \\ a clutch of new Asian turtle species since the late 1980s. But are they what \\ they seem? Rex Dalton reports on a herpetological débâcle.
}

T hey began emerging in the late 1980s: new species of freshwater and land turtles from the waterways and forests of China and Southeast Asia. By the late 1990s, more than a dozen had been described. And that posed a challenge for conservation biologists, who were already struggling to protect the region's existing turtles, which are threatened by poaching for food and traditional medicine. Conservation plans, it seemed, would have to be broadened to include the new discoveries.

Most of the new species hadn't made their scientific debuts in the usual way, by being discovered in their natural habitats by field biologists and described in the context of their surroundings. Ten of them had been bought by a New York veterinarian, William McCord, from two Asian reptile dealers, who said that they had acquired them in markets or isolated villages. From 1987, McCord and his academic collaborators began describing the specimens in specialist journals ${ }^{1-10}$ (see Table, overleaf).

Subsequent events have put the status of those specimens in serious doubt. In 1998, McCord's two dealer contacts were named in a US criminal indictment as members of the world's biggest ring of reptile smugglers. Shortly afterwards, an enterprising Californian graduate student began an inquiry that seems to have blown McCord's scientific claims apart. It now seems that six of the species described by McCord and his collaborators are hybrids that were possibly bred in captivity, and three are species that have been described under other names elsewhere in the literature. Only one seems to be unambiguously a new species.

Herpetologists might have been able to dismiss the experience as a mere embarrassment were it not for the conservation implications. Four of the probable hybrid turtles have already been named in the China Red Data Book of Endangered Animals, an official national handbook for wildlife conservation, as species that need study and possible protection. "There are very limited resources for turtle conservation in Asia," says James Parham of the University of California, Berkeley, the graduate student who highlighted the problems with the turtles' identities. "It would be extremely unfortunate if precious funds are wasted on hybrid species described from turtle farms."

Turtles and tortoises are struggling for sur-

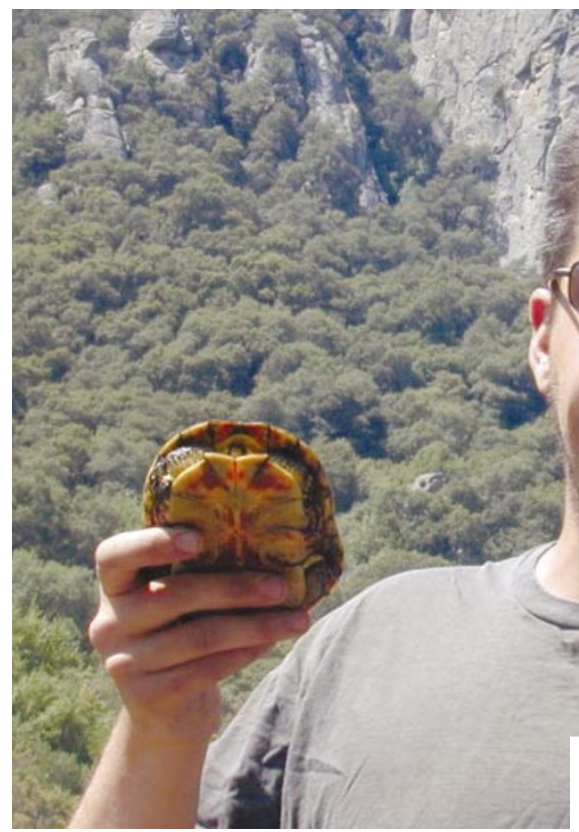

The taxonomy trail: investigations by James Parham and Haitao Shi (inset) revealed that farms in China are generating hybrid turtles that are very similar to animals that have been described as new species.

vival worldwide. Of the 90 or so species in Asia, the survival of about $75 \%$ is threatened. Given the size of the problem, the furore surrounding McCord's papers was the last thing that turtle conservationists needed. "This is very serious," says James Spotila, a herpetologist at Drexel University in Philadelphia, Pennsylvania, and a member of two World Conservation Union panels responsible for assessing the status of turtles. "There are obviously a lot of problems that need to be cleared up."

\section{Private investigations}

Until the current débâcle, McCord moved smoothly in herpetological circles. Indeed, he has published extensively on turtles in reputable journals. At his private East Fishkill Animal Hospital in Hopewell Junction, north of New York City, McCord maintains a collection of hundreds of turtles that rivals national facilities.

Some of these specimens were supplied by Keng Liang 'Anson' Wong, a dealer who was based in Penang, Malaysia, and Yuk Wah 'Oscar' Shiu from Hong Kong. Wong is now

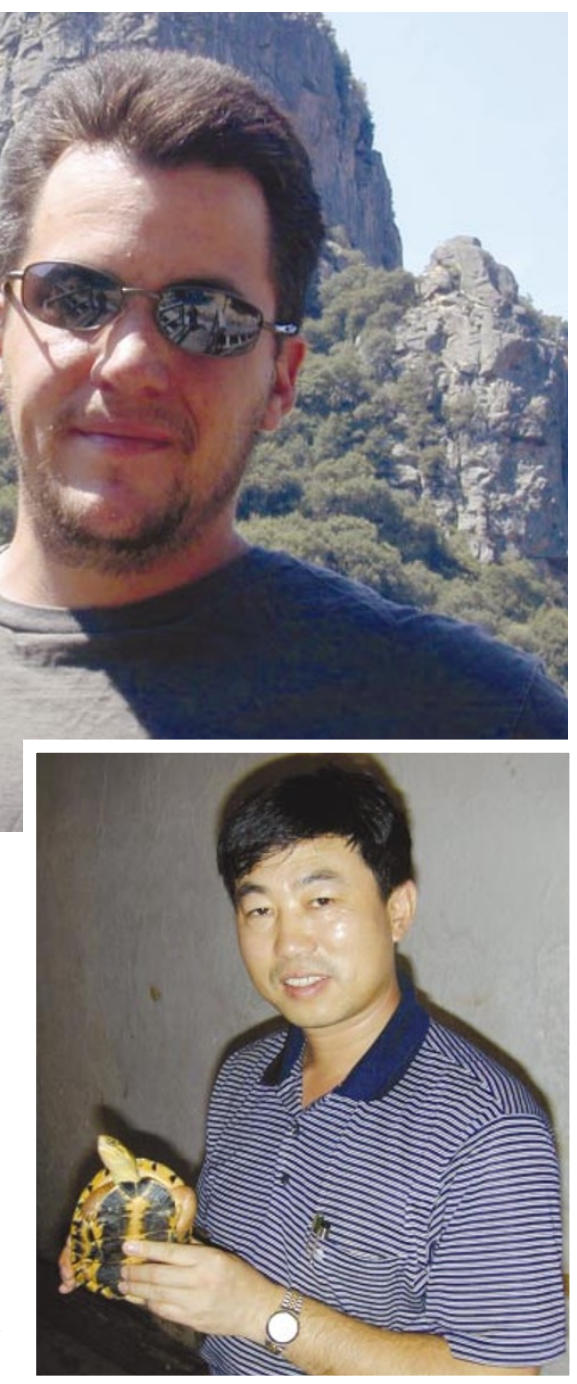

languishing in a US jail, serving a six-year sentence. Over the course of nearly a decade, US Fish and Wildlife Service agents coaxed the smuggling ring that Wong headed into sending rare reptile species to the United States. Wong was eventually lured to Mexico, where he was arrested. After fighting extradition for two years, he agreed to face US justice, pleading guilty in 2000 to 40 counts of reptile smuggling and money laundering. Four US accomplices were also convicted, and federal agents are now trying to extradite Shiu from Hong Kong. Records from the Grand Jury indictment in San Francisco suggest that Shiu provided $\$ 45,000$-worth of reptiles for 
shipment to the United States. Shiu did not respond to telephone messages left at his Hong Kong animal shop.

McCord stresses that the turtles he received were imported legally. Given that they were thought to be new species, they would not have fallen under the remit of the Convention on International Trade in Endangered Species of Wild Fauna and Flora, which regulates the wildlife trade. McCord also insists that his endeavours were for science and the preservation of turtles. He now acknowledges that he may on occasions have been "tricked" into buying farmbred hybrids. But he is holding out hope that some of the new turtles are "natural hybrids", having crossed in the wild on their own.

McCord still speaks positively of Shiu, with whom he collaborated in 1997 on a documentary film about the threats facing Asian turtles. "He risked his life to expose what is happening," McCord says. "I don't believe he intentionally lied."

Indeed, McCord has continued to publish on specimens provided by Shiu since the allegations of smuggling were made. Last year, McCord was a co-author on a paper ${ }^{11}$ by researchers at the University of California, Davis, on the genetic analysis of other turtle species. These included specimens collected for McCord by Shiu, reportedly from an isolated Chinese village near the border with Myanmar. Because of McCord's "longterm professional relationship" with Shiu, the article stated, "we feel confident in the accuracy of the locality data".

Having delved into other papers in which Shiu provided similar information, Parham doesn't share that confidence. Parham first began to question the identity of the new species described by McCord and his colleagues while conducting background research for his thesis on turtle palaeontology. "I was just a guy working on fossils," he says. But as his suspicions about McCord's

The 'golden coin' turtle (Cuora trifasciata), much sought after for food and medicine in Asia, is often crossed with other species to give hybrids that are then sold as the genuine article.

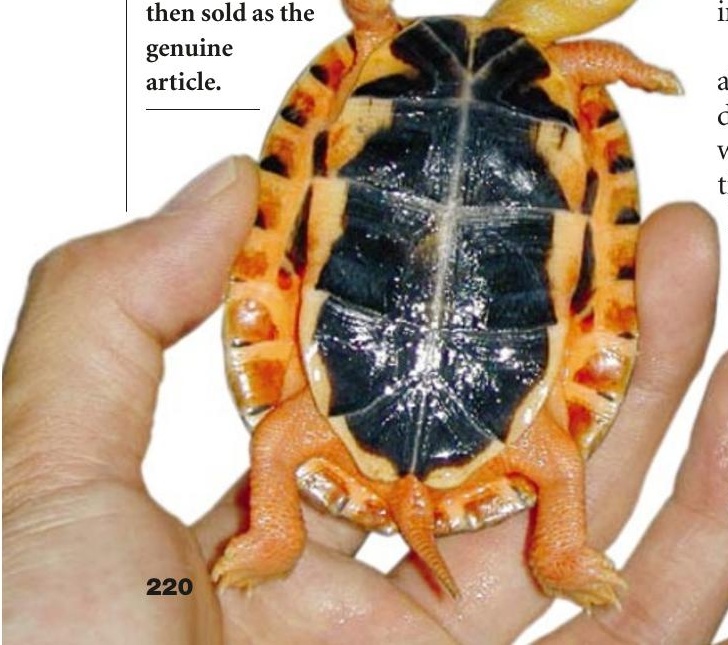

\section{The confused identity of Asian turtle species}

\begin{tabular}{|c|c|c|}
\hline Name & First citation & Status \\
\hline Cuora mccordi & Ref. 2 & New species \\
\hline Cuora chriskarannarum & Ref. 1 & Described elsewhere as Cuora pani \\
\hline Cuora pallidicephala & Ref. 3 & Described elsewhere as Cuora zhoui \\
\hline Cyclemys atripons & Ref. 9 & Described elsewhere as Cyclemys pulchristriata \\
\hline Mauremys iversoni & Ref. 4 & Indicated by genetic tests to be hybrid (Mauremys mutica $\times$ Cuora trifasciata) \\
\hline Mauremys pritchardi & Ref. 10 & Indicated by genetic tests to be hybrid (Mauremys mutica $\times$ Chinemys reevesii) \\
\hline Cuora serrata & Refs 7,15 & Indicated by genetic tests to be hybrid (Pyxidea mouhotii $\times$ Cuora galbinifrons) \\
\hline Sacalia pseudocellata & Ref. 6 & Probable hybrid (Cuora trifasciata $\times$ Sacalia quadriocellata) \\
\hline Ocadia glyphistoma & Ref. 8 & Probable hybrid (Ocadia sinensis $\times$ Mauremys annamensis) \\
\hline Ocadia philippeni & Ref. 5 & Probable hybrid (Ocadia sinensis $\times$ Cuora trifasciata) \\
\hline
\end{tabular}

identification of the specimens began to grow, Parham started to raise questions with other herpetologists - and began to hear dark rumours about turtle hybrids.

So began a two-year sojourn into the netherworld of the Asian turtle trade. Largely with his own funds, Parham made repeated trips to China, where he teamed up with Haitao Shi of Hainan University. Together, they visited turtle farms in Hainan province, where hybrids are bred for sale as food, medicine and to turtle collectors, finding specimens that matched the descriptions of the new species identified by McCord. The farms' proprietors acknowledged selling hybrids to dealers. Finally, in 2001, Parham and his colleagues published two papers ${ }^{12,13}$ detailing their findings, which included genetic analyses strongly suggesting that two of the species described by McCord are hybrids. Separate genetic analysis by a German group revealed that a third of McCord's specimens also seems to be a hybrid ${ }^{14}$.

\section{Identity crisis}

"Parham is the one person who pulled all this out in the open," says Carl Ernst, a herpetologist at George Mason University in Fairfax, Virginia, who collaborated with McCord in the late 1980s, identifying two apparently new turtle species ${ }^{1,2}$. One seems to be bona fide, but the other is now thought to be a previously identified turtle. After growing suspicious about the information supplied by Shiu about the localities in which the turtles had been found, Ernst stopped collaborating with McCord shortly after the papers were published. "The changing localities were driving me nuts," he says.

But when Parham first started talking about his findings at scientific meetings, his diligence in shedding light on the murky world of the turtle trade, and on the description of hybrids as new species in the scientific literature, wasn't universally appreciated. Parham says that he met with resistance and experienced professional attacks including a series of critical e-mails. And in 2001, an invitation to participate in a World Conservation Union workshop on endangered turtles at Fort Worth Zoo in Texas was suddenly withdrawn. Many of McCord's former collaborators have been left deeply embarrassed by the still-unfolding story. John Iverson, a herpetologist at Earlham College in Richmond, Indiana, named five new turtle species $3,5,6,8,9$ with McCord between 1989 and 1997; a sixth, described by Iverson and McCord as a new subspecies ${ }^{7}$, was later elevated to the status of a new species by other researchers ${ }^{15}$. Four of these turtles, including the elevated subspecies, are now thought to be hybrids; the remaining two examples are previously identified species. "I was trying to do good for turtles," says Iverson. "To some extent, it backfired." He stopped collaborating with McCord in 1998 , as soon as the indictment of Wong's smuggling ring came out.

Journal editors are now similarly contemplating the fallout of the affair. Richard Sternberg of the National Center for Biotechnology Information in Bethesda, Maryland, is editor of the Proceedings of the Biological Society of Washington, which published six of the papers describing the questionable species. He says that the journal will conduct an inquiry of its publications about dealer-supplied specimens to determine "if any fraudulent or illegally gathered data were unwittingly published".

Meanwhile, genetic studies to uncover the true identity of McCord's specimens are continuing. And that, unfortunately, means the expenditure of more time, money and effort that could have been devoted to conserving real, wild turtles.

Rex Dalton is Nature's US West Coast correspondent.

1. Ernst, C. H. \& McCord, W. P. Proc. Biol. Soc. Wash. 100, 624-628 (1987).

2. Ernst, C. H. Proc. Biol. Soc. Wash. 101, 466-470 (1988).

3. McCord, W. P. \& Iverson, J. B. Herpetologica 47, 407-420 (1991).

4. Pritchard, P. C. H. \& McCord, W. P. Herpetologica 47, 139-147 (1991).

5. McCord, W. P. \& Iverson, J. B. Proc. Biol. Soc. Wash. 105, 13-18 (1992).

6. Iverson, J. B. \& McCord, W. P. Proc. Biol. Soc. Wash. 105, 426-432 (1992)

7. Iverson, J. B. \& McCord, W. P. Proc. Biol. Soc. Wash. 105, 433-439 (1992)

8. McCord, W. P. \& Iverson, J. B. Proc. Biol. Soc. Wash. 107, 52-59 (1994).

9. Iverson, J. B. \& McCord, W. P. Proc. Biol. Soc. Wash. 110, 629-639 (1997)

10. McCord, W. P. Chelonian Conserv. Biol. 2, 555-562 (1997)

11. Engstrom, T. N., Shaffer, H. B. \& McCord, W. P. Biol. Conserv. 104, 173-179 (2002)

12. Parham, J. F., Simison, W. B., Kozak, K. H., Feldman, C. R. \& Shi, H. Anim. Conserv. 4, 357-367 (2001).

13. Parham, J. F. \& Shi, H. Asiatic Herpetol. Res. 9, 71-76 (2001).

14. Wink, M., Guicking, D. \& Fritz, U. Zool. Abh. Staat. Mus. Tierk. Dresden 51, 41-49 (2001).

15. Fritz, U. \& Obst, F. J. Zool. Abh. Staat. Mus. Tierk. Dresden 49, 261-279 (1997) 